\title{
SEPARATING SOCIAL WELFARE SERVICES AND SOCIAL WELFARE GRANTS: CHALLENGES AND OPPORTUNITIES
}

\section{RL September}

\section{INTRODUCTION}

As a consequence of the fundamental reconstruction and development processes, including a large-scale macroeconomic stabilisation strategy, South Africa's economic growth has consistently averaged 3\% over the last decade. It is expected that the government's new Accelerated and Shared Growth Initiative for South Africa (AsgiSA) will increase the economic growth rate from its current level to $4.5 \%$ by 2010 and $6 \%$ by 2014 (Yemek, 2006). Yet with the majority of its citizens living in poverty (with less than $\$ 1$ per day), South Africa remains one of the most unequal societies in the world (Statistics South Africa, 2004). Although there has been some improvement over the last decade, the stubborn legacy of apartheid persists and can be seen in the concentration of poverty and underdevelopment in black communities. Twenty four million of South Africa's population of 45 million are black females who live below the poverty datum line (Statistics South Africa, 2004). Using the expanded definition of unemployment, Statistics South Africa (2004) estimated that $41 \%$ of the economically active population was unemployed in 2004. There is, therefore, growing concern that the strategies employed thus far to raise the unacceptably low standards of living of South Africa's vulnerable populations, who continue to lack access to basic services and employment opportunities, are lagging far behind what is needed.

The government remains adamant that sustained economic growth will contribute to the reduction of South Africa's colossal socioeconomic inequalities. Through AsgiSA, the intention is to expand the redistributive benefits of economic growth towards those trapped in the second economy. The new AsgiSA restorative interventions are described as "broad-based development measures", which are intended to bring about better and long-term synergy between economic growth and poverty reduction, mainly to ensure that the poor become selfreliant. Examples of these "measures" include consistent efforts to reduce taxes on the corporate sector and lower-income households, expanded public works programmes, increased spending on social welfare grants, and restructuring of public service institutions providing pro-poor policies and programmes (Yemek, 2006). Through the Department of Social Development the government is increasing its spending on social welfare grants as a primary poverty-reduction strategy.

Access to social security (in South Africa primarily through welfare grants) as a socioeconomic right has been consistently debated over the last decade, with a strong lobby advocating for a comprehensive and inclusive Basic Income Grant (BIG) - a universal grant for all South Africans who are eligible for social security. But so far the government has resisted this development in favour of seven types of means-tested social welfare grants. Of these, three directly target children in need: (i) the Child Support Grant (CSG) payable to the primary caregivers of children under fourteen years of age; (ii) the Care Dependency Grant, which is available to parents or caregivers of children with mental or physical disabilities; and (iii) the Foster Care Grant for foster parents of children in foster care until they reach the age of 18 years. 
If it is accepted that the high levels of poverty in the country will persist in the short to medium term, then it is also highly likely that income support to the "poorest of the poor" would remain a key government priority. Accordingly, since 2001 social welfare grants have been the fastest growing category of government expenditure. At present they reach 10 million beneficiaries at an annual cost of R70 billion (Manuel, 2006). This escalating demand for social welfare grants was one of the main reasons for the separation of social welfare services and social security. It was particularly troublesome that, at the provincial level, social welfare grants were "crowding out" the budget for essential education, health and social welfare services. Even the wealthiest provinces, namely, Gauteng and the Western Cape, spent less than $10 \%$ of their budgets on social welfare services, while on average social welfare grants consumed over $86 \%$ of provincial budgets (September, 2004; Streak \& Van der Westhuizen, 2004). At this rate the demand for social welfare grants places the under-resourced social welfare system under enormous pressure.

In this paper I discuss this significant policy shift and its consequences for social welfare services in South Africa and, reflecting on the imperative relationship between social welfare services and social welfare grants, I argue that, unless the government ensures that the basic needs of the poor are met through other development strategies, they will continue to enter a social welfare system that is not designed for this purpose. Moreover, it will destroy what is left of the child welfare system (a core function of social welfare services), which is already struggling to cope with the demands of the increasing numbers of children orphaned through HIV/AIDS as well as the massive resource implications associated with implementing the new comprehensive Children's Act by 2008.

\section{SEPARATING SOCIAL WELFARE SERVICES AND SOCIAL WELFARE GRANTS}

In South Africa social welfare services are delivered by the national Department of Social Development (DSD) and its nine provincial departments with the support of the business sector and a range of civil society organisations, including private welfare organisations (PWOs), non-governmental organisations (NGOs), community-based organisations (CBOs), and faith-based organisations (FBOs), each with a unique history. Before the separation of its core functions, the DSD organised its services into three main categories.

- Social grants payable on a means-tested basis to the aged, disabled, war veterans, and children and families.

- Social welfare services, including the prevention, care and protection of children, youths and families in a range of services, such as child protection, youth development, substance abuse, HIV and AIDS, and care for disabled and older persons.

- Community development and relief programmes, including food relief and communitybased development projects aimed at poverty alleviation (DSD - Department of Social Development, 2004b).

With the passing of the Social Assistance Act (Act 13 of 2004) and the South African Social Security Agency (Act 9 of 2004), the government formally separated social welfare grants and social welfare services. Its primary aim was ostensibly to ensure the accelerated implementation, monitoring and evaluation of social security as a direct poverty-alleviation measure through the South African Social Security Agency (SASSA), a single national statutory agency intended to mainstream norms and standards for social security, which reports directly to the Minister of Social Development. 
Prior to the separation, provincial social welfare services' expenditure came primarily from the central budget with local and provincial government being allocated an "equitable share" of national government revenue as recommended by the Financial and Fiscal Commission. In addition to social welfare grants, especially the child support and disability grants, and emergency social assistance for food relief and HIV and AIDS, the government also made "conditional grants" - earmarked for special purposes, such as disaster management - available to the provinces. However, even with this additional relief, provincial spending on social welfare services grew from R20.9 billion in 2000-2001 to R42.4 billion in 2003-2004, an average growth of 26.6\% (FFC - Financial and Fiscal Commission (FFC), 2004). It also grew proportionately from $18.9 \%$ of the total provincial expenditure in $2000-2001$ to $24.8 \%$ in 2003 2004. Notwithstanding the adjusted estimates that provinces were allocated for social welfare grants, in this period there was a cumulative over-expenditure of R1.5 billion on social welfare services budgets (Streak \& Van der Westhuizen, 2004).

According to the intergovernmental financial reports (FFC, 2003, 2004), this growth resulted mainly from social welfare grants. Overall, the government's spending on social welfare grants increased from R2.9 million in April 2000 to R7 million in April 2004. The phasing-in of the child support grant, incrementally introduced over three years to cover children until they reached 14 years of age, alone increased from R1.2 billion in 2003-2004 to R9.3 billion in 2006-2007.

For the most part, concerns raised by economists as to the sustainability of this level of social welfare grant expenditure led to the government's decision to separate social welfare grants from social welfare services. When the escalation reached an estimated annual growth of $20 \%$, both the government and the FFC warned that the South African economy would not be able to sustain this rate of growth in the long term (Manuel, 2004). In fact, as early as 2000 the FFC reported that the complexity and diversity of social welfare services made the costing and measuring of output indicators difficult to achieve (FFC, 2003). In this regard, welfare economists generally agreed that social welfare services were difficult to define and, therefore, difficult to quantify and to cost (Glennerster, 2003). The National Treasury also claimed that the difficulties of reaching precise conclusions about social services spending trends were due to the "lack of uniformity in their classification ... as well as the weak information systems" (FFC, 2003). Consequently, in its submission for the 2004-2005 division of revenue, the FFC proposed that:

- the allocation to welfare should accurately reflect spending on welfare services;

- the amounts allocated for social security and social welfare services should be assigned separately;

- the allocation for social welfare services could be based on an indicator of the proportion of the population below the poverty line;

- the social development allocations should be reviewed to reflect specific needs in the provinces;

- the components in the formula should be determined by explicit policy guidelines on minimum norms and standards.

With the separation of social welfare and social security (a policy shift) it was therefore expected that the SASSA would remedy the huge administrative delays and facilitate speedy payment of the grants to eligible people, while at the same time reducing corruption and addressing underdevelopment. From its inception the new agency had to deal with an administrative system rife with fraud, corruption and maladministration. To date, through its 
comprehensive anti-fraud strategy and special investigation unit, 32000 cases have been reported and investigated and more than 600 government officials have been arrested, of whom 400 have been convicted of malpractice (SASSA, 2006). Government intensified its focus on social welfare grants and expanded the capacity and infrastructure of SASSA to deal with the increasing demand for grant applications. It was clear that the new SASSA remained government's main priority, while social welfare services received even less political and administrative attention.

While government's budgets allocated for social security and social welfare services are now assigned separately, the consequences of this connectedness are only now being appreciated with the increasing demand for welfare grants that target predominantly vulnerable children. All of these children live with poor families who depend on social welfare intervention. In addition, the pressure on government is most severely felt with the increasing numbers of children who are orphaned through HIV and AIDS and as a result drawn into the foster-care system. The Actuarial Society of South Africa (ASSA) reported that in July 2005 there were 3.4 million children in South Africa who have lost one or both parents (Children's Institute, 2005). At the end of 2004 there were a total of 236000 children in foster care. The majority of the relatives who are in a position to care for these children also depend on the Foster Care Grant (FCG) and for each grant and foster care placement, there are extensive associated social welfare services.

Moreover, the implications of implementing the new Children's Act also forced the crisis in the sector to the fore. In terms of the Public Finance Management Act, a memorandum of the financial implications should be tabled in Parliament along with all proposed legislation. As custodian of the Children's Act, the Department of Social Development commissioned Cornerstone Consultants to conduct the costing. The Cornerstone report indicates that the key financial implication of implementing the Children's Act relates to the cost of protection services, foster care and kinship care. For example, there are presently 285 children's homes with a capacity of 13984 children. In a high-demand scenario, the demand for places in children's homes will be 154606 with 2391 children's homes needed. The cost to make up the backlog is calculated at around R9.7 billion (Barberton, 2006).

Although the Cornerstone report only deals with child welfare services, which constitutes the bulk of the services, it proves that the sector is hugely under resourced. The most important implications of these trends in the sector are related to (i) the number of social workers needed to sustain a functional child welfare system; (ii) the capacity of the organisations that employ them - in particular the private welfare organisations; (iii) how government designs and resources social welfare services, and dovetails its poverty-reduction strategies currently fragmented across many departments. I discuss these next.

\section{THE IMPACT ON CHILD WELFARE SERVICES AND THE INCREASING DEMAND FOR SOCIAL WORKERS}

It is evident that the restructuring and the expansion of the new social security system will have far-reaching consequences for social workers. In South Africa social workers are the cornerstone of the child-protection system. The quality of their decisions, especially in Children's Court Inquiries (CCIs), directly impacts upon the shape and size of the social welfare grants. The courts rely heavily on the recommendations of social workers regarding the long-term care and protection of children in need of care. Several options are usually considered, including the options of living at home with parents or guardians or out-of-home care placements (residential care or foster care). The Children's Court may order any of these 
options. In the case of out of home placements, the government carries the costs. In financial terms, out-of-home care is always the more expensive option. For a government with fiscal constraints, such as South Africa's, this is an important consideration. For example, this option will cost more in the form of subsidies payable to children's homes, youth care facilities and foster-care grants and has significant bearing on the numbers of social workers needed, their training and their working conditions. But already in 1996, in the first draft of the National Strategy on Child Abuse and Neglect, the child welfare system was described as "dismal ... falling apart" and in crisis (DSD, 1996). The instances of child abuse, neglect and exploitation in the country are still escalating dramatically (September, 2005; Loffell, 2004). Police statistics for 2004/2005 reveal that children represent 40.8\% (22 486) of all reported rapes (55 114 ) in South Africa and that 1128 children were murdered during the same time period (Cape Argus, June 2006).

The ever-increasing numbers of children being orphaned by HIV/AIDS and the associated demand for foster care grants caused a huge backlog in the already over-stretched administrative procedures and children's court inquiries, which considerably increased the demand for social workers. Every foster-care placement must be thoroughly assessed, a permanency plan developed for each child and carefully monitored by a qualified social worker. In addition, ongoing recruitment, training and support to foster-care parents is a service currently only provided by social workers.

The most substantial cost implication in the Cornerstone report is the cost of employing the large number of social workers and auxiliary social workers that will be required to implement the new Children's Act by 2008. The total number of social workers in South Africa in 2003 was 10 515. The report indicates that almost three times more social workers are presently required and that by 2010 some 16504 will be required. The norm for social workers to population used by the DSD (taking into consideration urban and rural diversity) is between 3000 and 5000 per social worker. If the high-demand scenario in the report is used, the number of social workers that will be needed by 2010 can be 55000 . These calculations provide an indication of the extent of the need. Social work is the profession primarily associated with the direct delivery of social welfare services. However, it is becoming increasingly difficult to recruit and retain social workers in the sector as a result of the poor earnings and poor working conditions, mostly related to the lack of resources such as transport to do the job, burnout and dissatisfaction because other social service sectors are often better paid (DSD, 2004a). But it is mainly the social workers who are at the coalface of policy implementation and therefore also at the frontline of criticism for non-delivery. In the workplace they feel frustrated and complain about the vague, ambiguous and conflicting goals of their mandate and the lack of standardised guidelines for intervention (Lombard, 2004; Hartley \& Mabuza, 2004; McKay, 2003; McKendrick, 1998; September \& Blankenberg, 2004). Within this context international recruitment agencies continue to recruit qualified South African social workers successfully with offers of better pay and working conditions that cannot be matched in this country.

There seems to be emerging evidence that this crisis in the child welfare system, coupled with the fiscal implications of implementing the new Children's Act, may force the government to reassess its ambivalent position on child welfare services in general, but particularly in regard to the important role of social workers and the contribution of the non-government social welfare sector. In response to the crisis the DSD's Scarce Skills Policy Framework (DSD, 2003) declared social work a scarce skill. In line with this policy framework the DSD is currently providing study bursaries to prospective social workers and improving social work salaries for social workers employed in the public sector (DSD, 2004a). While the numbers of 
social workers in government must be increased, it is evident that the large-scale inadequacies of the overall delivery systems will require substantively more resources. The government will have to seriously enhance civil society partnerships to increase capacity. In this regard its relationship with the non-governmental welfare sector is especially critical.

\section{THE NGO SECTOR - A CRITICAL PROVIDER - IN CRISIS}

The non-governmental social welfare, community-based and faith-based organisations continue to play a crucial role in delivering social welfare services in South Africa. The National Coalition for Social Services (NACOSS) is an umbrella organisation with a membership of 4,000 civil society organisations that provide social welfare services in the country. The sector employs more than 2000 social workers, who serve more than 3600 welfare services, costing more than R1.3 billion per annum and benefiting more than 11.5 million people. Collectively these organisations employ more than 26000 people, and at least 42000 volunteers are involved in their activities at national, provincial and local level (Mokgata, 2004). They are mostly located within communities and therefore provide closer access and engagement with the poorest communities. Besides its long history of providing a wide range of formal child and family welfare services, the sector has also during recent years expanded its role extensively to provide critical services in support of the government's programme to accelerate children's access to child-support grants and HIV/AIDs support services, especially in rural areas. However, despite its important contribution, the sector is often excluded from social welfare services planning and is seriously under-funded (NACOSS, 2003). For this reason the relationship between this sector and the government has been strained for many years. Regrettably, this ongoing unresolved problem will have a considerable impact on the quality and the scope of service delivery. The lack of adequate funding means that numerous children (often AIDS orphans) are "stuck" in the judicial system with large backlogs of foster-care applications requiring investigation. For example, one organisation reported that it has a backlog of more than 1400 cases, which is increasing at a rate of almost 100 cases per month. Children's homes have also increasingly been unable to sustain services and some had to be closed down. The fact that the government's residential care facilities are run at R5 699 per child per month and the government pays NGO children's homes an average of only R857 per child per month starkly represents the crisis (NACOSS, 2003).

In its submission to the government on the retention of social workers, NACOSS stated that it is also impossible to retain social workers in the sector because of the low salaries that the sector can afford to pay them. The salaries of social workers in the NGO sector are based on the subsidies that government pays. In addition, these subsidies are not standardised nationally. The remuneration of social workers working for the government is much better; as a result NGOs lose them to government (NACOSS, 2006). This sector has the infrastructure, capacity and experience to deliver the services that are now in crisis because of the increasing demand. To cover the expanding need for service, the sector is employing other categories of social service professionals such as auxiliary social workers and community development workers.

Although there is wide support for the position that the government must provide all statutory child-protection services, in the short term it is apparent that the NGO sector is a critical provider of especially child welfare services and will have to continue in order to break out of the enduring crisis. The country would therefore be best served if the government provides this sector with adequate resources based on clear expectations and standardised national funding policies. 


\section{FAMILIES IN POVERTY NEED MORE THAN THE SOCIAL WELFARE SERVICES CAN OFFER}

At least conceptually social welfare grants and social welfare services constitute two equally important pillars of social development. But because they are not strategically aligned, not adequately resourced and not implemented in a coordinated and integrated way, vulnerable children and their families fall through the cracks. For example, poor children are more likely to enter the child-protection system and are more likely to be on social welfare grants than children from middle- or upper-class families (Waldfogel, 2003). These families who often have multiple needs remain in the child welfare system from one generation to the next (cycle of poverty). Once in the welfare system, their problems become highly visible and they are most likely to exhibit problems of abuse or neglect (Loffell, 2004; September, 1998; Waldfogel, 2003), so that their children are more likely than those not in the child-protection system to be placed in out-of-home care. Shook (2002) reported that the risk of being involved in child-protection services increases over time and that the risk is highest among families who remained on welfare and where family members were unemployed (Waldfogel, 2003).

The main issue for many of these families is one of resources and most do not have the education to move into formal jobs, even if these were available. Income support through welfare grants is therefore essential for these families. If they are on social welfare grants, and if the system is aligned to social welfare services, then early detection coupled with intensive, holistic, family-focused services could assist many of these families to escape long-term dependence on social welfare grants and family disintegration - for example, programmes offered to substance-abusing parents, teenage parents, interventions aimed at keeping children in schools until they complete high school, and assistance to obtain housing and employment.

However, in South Africa child and family welfare services are mostly geared towards crisis intervention with a predominant child-protection focus. While there is general consensus that most of these families have multiple difficulties, including poverty and unemployment, because of social workers' huge caseloads (September, 2005) and severe resource constraints, very few of these families receive such long-term intensive family-centred services. The result, notwithstanding the good theoretical intentions of family preservation work, is that in South Africa this service is embedded in a social welfare system that faces grave difficulties.

There is also growing recognition in the sector that, although the demand for more foster-care grants is associated with the increased number of orphans, indications are that this grant is doubling up as a poverty-alleviation system (Loffell, 2005; September, 2006). The fact that, at R560 per month, this grant is also substantially more than the Child Support Grant (CSG) of R180 (Loffell, 2004; September, 2006) triggered a serious demand for this grant rather than any other welfare grant. From this perspective it can be argued that social welfare grants targeting individuals in households are, in fact, "poor family" support grants. For example, three of the seven types of the grants are aimed primarily at providing support to children when their needs cannot be separated from those of their families. In addition, the broader targeting of households rather than individuals - those receiving minimal old age pensions, for example - could result in a basic income-support programme sufficient for poor families' needs. In these families many grandparents are the primary caregivers as their children have died of HIV and AIDS-related illnesses. In effect, social welfare grants are often the only income for thousands of South African households.

At present, this constitutes a huge challenge for social workers, who are best trained to intervene in matters of social welfare on a remedial and clinical basis. The infrastructure 
(including financial resources and the qualifications of the work force) of social welfare organisations is not designed to meet this wide range of socio-economic needs. Consequently, the same families and children are often "recycled" in different parts of the helping system.

While the policy changes facilitated through the White Paper for Social Welfare (1997) stimulated the development and implementation of broader poverty-reduction interventions, they are not mainstreamed in all social welfare organisations, and neither do they necessarily involve the families who are on child welfare case loads. Poverty-reduction projects are mostly implemented by community development workers employed at local government municipalities.

The Minister of Social Development, Dr Zola Skweyiya (2006), recently asserted that his mandate was to look after the needs of the poorest of the poor, and their primary means of survival was the social security benefits, especially in rural areas. Poverty levels are higher in the more rural provinces, with a concomitantly greater need for social workers but, without exception, these provinces have the fewest practitioners and the least resources. The lack of resources for appropriate social welfare services in these areas will inevitably mean an increased need for long-term social welfare grants. However, global evidence attests to the limitations of income support in improving the quality of people's lives (Buckley, 2005; Midgley, 1995). The same Minister criticised the other departments, whose "tardiness or failure to provide services" often meant that the grants were not used as intended. These other departments included those responsible for ensuring that the poor had free access to water, housing and education. The same could be said about linking the poor with employment opportunities provided by the Department of Labour's skills development programmes through the Sector Education and Training Authorities (SETAs) and the Department of Public Work's Expanded Public Works Programme (EPWP) aimed at increasing employment opportunities for un-skilled and semi skilled labour.

Clearly the intended holistic planning of integrated service delivery is not backed up with adequate inter-departmental and institutional mechanisms, resources and even shared goals. This is evident in that, with the increasing demand for social security benefits, the Minister of Finance Trevor Manuel (2006) asked Parliament assertively: "Is our vision of a future South Africa one in which over $20 \%$ of the population depends on welfare for their livelihoods"?

South Africa is obviously struggling to make these critical connections among its povertyeradication strategies. Also, the strategies that do exist are limited in scope, are often not adequately evaluated and therefore not taken to scale in order to reach more significant numbers of people who could potentially benefit from tested and tried best practices.

\section{THE FUTURE OF SOCIAL WELFARE SERVICES LIES IN PRIORITISING WHAT IT DOES BEST}

The Cornerstone report provides crucial information about the resource crisis in the sector. But equally important: it raises the question of whether the present models of social welfare services delivery in South Africa are appropriate for the country in view of the scope and nature of the problems presented. Furthermore, given the lack of information systems, the problems of reliable data and capacity constraints within provinces, much more relevant research studies must be done to develop evidence-based social welfare programmes, uniform service standards and appropriate costing norms for social welfare services.

The sector must seriously consider how the emerging trends in social welfare impact upon future resources, policies, systems and implementing mechanisms, both public and private. In 
this regard, the Department of Social Development may have to prioritise those activities that are closest to what it can accomplish best in terms of workforce competencies and financial capacity. In order to move closer to robust, efficient and effective social welfare services, the sector must engage in a comprehensive process which defines what it does and how it does it; it needs to calculate what it will cost, ensure accountability, and set performance standards, outcome measures and monitoring mechanisms; it will also have to conduct ongoing research that develops evidence-based practice and contributes centrally to the reconstruction and development of social welfare services.

As a starting point, it is essential for the sector to refocus its future mandate on what it can realistically achieve and be able to demonstrate that the resources allocated for social welfare services are well spent. This may well involve cutting back on the broad social development agenda as defined in the White Paper (Department of Welfare and Population Development, 1997). The comprehensive reassessing of social welfare services will also provide the opportunity to align welfare services and social welfare grants with other critical social development strategies of government as proposed in the new Accelerated and Shared Growth Initiative for South Africa (AsgiSA).

Social work as a profession has long demonstrated the extensive range of social work interventions that can contribute towards social development. Since 1994 the repertoire of social work interventions has diversified significantly within the context of developmental social welfare services (Patel, 2005). However, within the current context, where the demand for social work services is overwhelmingly felt in child-protection services and the number of social workers vastly inadequate, it may be necessary for the sector to consider if this is not where the specific knowledge, skills and competencies of social workers would be most effective. To alleviate the pressure from the thousands of families on social welfare grants and who are in need of ongoing family-centred services or foster-care support services, the growing new categories of social service professionals - such as child and youth care workers, assistant probation officers and community development workers - could be employed. Even with this relief, the implications of the new Children's Act are such that the bulk of statutory child-protection services will still remain the exclusive terrain of designated registered social workers. Given the extent of these capacity gaps, the government will have to make crucial decisions about the role of the non-government social welfare sector, if these organisations are expected to continue to provide the vital social welfare services.

\section{CONCLUSION}

The selling power of the developmental vision of the Department of Social Development lies in the realisation of its operational connectedness to the essential strategies of the government's poverty-reduction framework (AsgiSA). AsgiSA will most probably achieve its economic growth objectives, the question is will it create enough jobs and social well being? In this paper I have argued that the needs of people entering the social welfare services are not homogenous; rather, they are complex and must be understood and served by a range of interconnected supports and resources. Children and families on both sides of the separated functions of social development, i.e. social welfare grants and social welfare services, are often the same families. Unless these service systems are strategically and operationally "integrated", their clients' primary needs will go unmet. Separating social welfare services and social welfare grants provides an excellent opportunity for the government to engage in a comprehensive process of defining what it does, how it does it, what it will cost, what performance and accountability measures it needs to implement, and the strategic partnerships 
it needs to deliver. To do this the Department of Social Development must urgently enhance the leadership and research capacity that are required and which are essential for an evidencebased process of reconstructing and developing a new social welfare service for the country.

Finally, the non-equitable distribution of resources in the country is a key barrier in the delivery of social welfare services. This situation must change, if the profession's solidarity with the poor is to be realised through the envisioned "development of human capacity and self-reliance in partnership with all stakeholders through an integrated social welfare system which maximises its existing potential, and which is equitable sustainable, accessible, peoplecentred and developmental" (Department of Welfare and Population Development, 1997:7).

\section{REFERENCES}

BARBERTON, C. 2006. Estimates of the costs to Government of the Comprehensive Children's Bill for the period 2005 to 2010. Cornerstone, Economic Research. Unpublished document.

BOND, P. 2002. Fanon's warning: A civil society reader on the new partnership for Africa's development. Trenton, NJ: Africa World Press.

BUCKLEY, H. 2005. Reviewing children first: Some considerations. Irish Journal of Family Law, 3:2-8.

CAPE ARGUS. 2006. Children victims in 40\% of reported rape cases. Wednesday, 28 June: 5. CHILDREN'S INSTITUTE. 2005. Child gauge. Cape Town: University of Cape Town.

DEPARTMENT OF SOCIAL DEVELOPMENT (DSD). 2003. Scarce Skills Policy Framework. Pretoria: Department of Social Development. Unpublished document.

DEPARTMENT OF SOCIAL DEVELOPMENT (DSD). 2004a. Retention strategy. Pretoria: Department of Social Development. Unpublished document.

DEPARTMENT OF SOCIAL DEVELOPMENT (DSD). 2004b. Strategic plan of the Department of Social Development 2003/4-2005/6. Pretoria: Department of Social Development.

DEPARTMENT OF WELFARE AND POPULATION DEVELOPMENT. 1996. Policy recommendations of the Inter-ministerial Committee (IMC) on Young People at Risk. Pretoria. Unpublished document.

DEPARTMENT OF WELFARE AND POPULATION DEVELOPMENT. 1997. White Paper on Social Welfare. Government Notice no. 1108, Government Gazette 386(18166), 8 August. Pretoria: Government Printer.

FINANCIAL AND FISCAL COMMISSION (FFC). 2003. Annual report (2002-2003). Midrand and Cape Town: Financial and Fiscal Commission.

FINANCIAL AND FISCAL COMMISSION (FFC). (2004). Annual report (2003-2004). Midrand and Cape Town: Financial and Fiscal Commission.

FRASER-MOLEKETI, G. 2006. All for one is the state's plan. Fraser-Moleketi sets out how the government will put a single public service in place. Sunday Times, 17 December: 15.

GLENNERSTER, H. 2003. Understanding the finance of welfare, what welfare costs and how to pay for it. London: Polity Press. 
GOVERNMENT COMMUNICATION AND INFORMATION SYSTEM (GCIS) 2003. Ten years of freedom: South Africa 1994-2004. Available: www.gcis.gov.za/docs/publications/10years.htm.

HARTLEY, W. \& MABUZA, E. 2004. Social grants: An aid for those in "second economy". Business Day, 19 February.

INTERNATIONAL FEDERATION OF SOCIAL WORKERS AND INTERNATIONAL ASSOCIATION OF SCHOOLS OF SOCIAL WORK. 1997. In: DEPARTMENT OF WELFARE AND POPULATION DEVELOPMENT, WHITE PAPER ON SOCIAL WELFARE. Notice 1108 of 1997, Government Gazette, 386 (18166), 8 August 1997.

KARGER, H. \& STOESZ, D. 1990. American social welfare policy: A structural approach. New York \& London: Longman.

LOFFELL, J. 2004. Policy responses to child sexual abuse in South Africa. In: RICHTER, L. DAWES, A. \& HIGSON-SMITH, C. (eds) Sexual abuse of young children in Southern Africa. Cape Town: Human Sciences Research Council.

LOMBARD, A. 2004. The professional identity and rights of social workers as social service professionals. Paper presented at the National Conference for Social Service Professions. Pretoria, 25-27 October.

MANUEL, T. 2004. Wage gap a threat. Business Report, 29 October.

MANUEL, T. 2006. Budget speech. Parliament, Cape Town.

McKAY, P. 2003. Welfare in crisis: Social workers face war of attrition. Children First, 7(50):14-15.

McKENDRICK, B. 1998. Social work education and training: From preparing for apartheid society to training for a developing democracy. Social Work/Maatskaplike Werk, 34(1):99_ 111.

MIDGLEY, J. 1995. Social development: The developmental perspective in social welfare. London: Sage Publications.

MINISTRY FOR WELFARE AND POPULATION DEVELOPMENT. 1995. Draft White Paper for Social Welfare. Government Gazette, 368(16943), 2 February. Pretoria: Government Printer.

MOKGATA, S. 2004. The NGO sector in crises. Paper presented at the National Conference for Social Service Professions. Pretoria, 25-27 October.

NACOSS - NATIONAL COALITION FOR SOCIAL SERVICES. 2003. Memorandum submitted to the Minister of Social Development, Dr Zola Skweyiya, March. Unpublished document.

NACOSS - NATIONAL COALITION FOR SOCIAL SERVICES. 2006. Comments on the draft recruitment and retention strategy for social workers in South Africa, June. Unpublished document.

NEUGEBOREN, B. 1985. Organisation, policy and practice in the human services. New York: Longman. 
PATEL, L. 2004. Toward a strategic funding model for developmental welfare services. Paper presented at the National Conference for Social Service Professions. Pretoria, 25-27 October.

PATEL, L. 2005. Social welfare and social development in South Africa. Oxford: Oxford University Press.

SASSA UPDATE. 2006. Fraud \& Corruption. 11-12. Department of Social Development, Pretoria. January/February.

SEPTEMBER, R. \& BLANKENBERG, C. 2004. A quest for excellence in multidisciplinary child protective services: An exploratory review. Child and Youth Research and Training Programme, University of the Western Cape, Cape Town.

SEPTEMBER, R.L. 1998. The development of a protocol for the management of child abuse and neglect. Cape Town: University of the Western Cape. (PhD thesis)

SEPTEMBER, R.L. 2004. Beyond Social Security: Trends and Options for Developmental Social Welfare Services in South Africa. Commissioned research for the Financial and Fiscal Commission. Unpublished report.

SEPTEMBER, R.L. 2005. Protecting children where it matters most: In their families and communities. Social Work/Maatskaplike Werk, 41(1):27-37.

SEPTEMBER, R.L. 2006. A review on the status of child protection services in South Africa: State of the art policies in need of implementation. Social Work/Maatskaplike Werk, 42(1):54-67.

SEWPAUL, V. \& HOLSCHER, D. 2004. Social work in times of neoliberalism: A postmodern discourse. Johannesburg: Van Schaik.

SHERRADEN, M. 1991. Assets and the poor: A new American welfare policy. New York: Armonk.

SHOOK, K. 2002. In: WALDFOGEL, J. (ed) 2003. Welfare reform and the child welfare system. Paper presented to the Joint Center for Poverty Research, Washington, DC. 20-21 March.

SKIDMORE, D. 2000. Civil society, social capital and economic development. Available: www.drake.edu/artsci/PolSci/personalwebpage/socialcapital.html [Accessed:15 May 2006].

STATISTICS SOUTH AFRICA . 2004. General household survey July 2004. Statistical news release P0318. Pretoria, Statistics South Africa.

STREAK, J. \& VAN DER WESTHUIZEN, J. 2004. Fitting the pieces together: A composite view of government's strategy to assist the unemployed in South Africa 19942004. Cape Town: Idasa Budget Information Service.

SKWEYIYA, Z. 2006. Ready for big fight to have social grants hiked, Sunday Times, 10 September: 7.

SWILLING, M. \& RUSSELL, B. 2001. The size and scope of the non-profit sector in South Africa. Durban: Centre for Civil Society, University of Natal.

YEMEK, E. 2006. Budgetary perspectives on shared growth policy interventions in South Africa. Unpublished Occasional Paper: IDSA, Cape Town. 
VAN WORMER, K. 1997. Social welfare: A world view. Chicago: Nelson-Hall.

WALDFOGEL, J. 2003. Welfare reform and the child welfare system. Paper presented to the Joint Center for Poverty Research, Washington, D.C, 20-21 March.

WIKIPEDIA. 2006. Human development theory. Available: http://en.wikipedia.org/wiki/Human_development_theory [Accessed: 15 May 2006].

Prof Rose September, Institute for Child and Family Development, University of the Western Cape, Bellville, South Africa. 